\title{
ANALISIS CUACA PADA PENERAPAN TEKNOLOGI MODIFIKASI CUACA DI DAS PLTA Ir. PM NOOR BULAN APRIL - MEI 2017
}

\author{
Weather Analysis of Weather Modification Application on the Ir. PM Noor \\ Hydroelectric Plant Catchment Area in the Months of April-May 2017
}

\author{
Purnomo Arif Abdillah ${ }^{1)^{*}}$, Muhamad Djazim Syaifullah ${ }^{2)}$, Rini Mariana Sibarani ${ }^{3)}$ \\ ${ }^{1,2,3)}$ Balai Besar Teknologi Modifikasi Cuaca - Badan Pengkajian dan Penerapan Teknologi, Gedung Ir. \\ Mohammad Soebagio, GEOSTECH (820), Kawasan PUSPIPTEK, Serpong, Tangerang Selatan \\ *Email : purnomo.arif@bppt.go.id
}

\begin{abstract}
Intisari
Pelaksanaan Teknologi Modifikasi Cuaca (TMC) di DAS PLTA Ir PM Noor dilakukan pada tanggal 18 April sampai 17 Mei 2017. Kondisi cuaca selama pelaksanaan kegiatan TMC dipengaruhi oleh adanya fenomena ENSO Netral dengan adanya kemungkinan menuju Nino lemah, sedangkan nilai anomali OLRnya lebih dominan negatif. Massa udara yang masuk daerah target didominasi massa udara yang berasal dari Lautan Pasifik Barat dan Laut Banda yang cukup mengandung uap air, kondisi kelembapan udara di wilayah Kalimantan Selatan cukup basah dan terdapat daerah konvergensi yang mendukung terjadinya pertumbuhan awan. Total rata-rata curah hujan wilayah di DAS PLTA Ir. PM Noor selama periode pelaksanaan TMC adalah sebesar 205,7 mm.
\end{abstract}

Kata Kunci : ENSO, Angin Gradien, Suhu Muka Laut, Kelembapan Udara, Hujan.

\begin{abstract}
The implementation of Weather Modification Technology in the Ir. PM Noor hydroelectric plant catchment area was conducted on 18 April to 17 May 2017. Weather conditions during the implementation of weather modification are influenced by the phenomenon of neutral ENSO condition with the possibility to Nino weak, while the value of the OLR anomaly is more dominantly negative. The air mass that entering the target area is dominated from the West Pacific Ocean and Banda Sea which contains enough moisture, the humidity conditions in South Kalimantan are quite wet and there is a convergence area that supports the occurrence of cloud growth. Total average rainfall in the Ir. PM Noor hydroelectric plant catchment area during the weather modification implementation period is $205.7 \mathrm{~mm}$.
\end{abstract}

Keywords : ENSO, Gradient Wind, Sea Surface Temperature, Relative Humidity, Rain.

\section{PENDAHULUAN}

Pembangkit Listrik Tenaga Air (PLTA) Ir. PM Noor merupakan salah satu unit pembangkit andalan bagi sistem kelistrikan di wilayah Kalimantan Selatan dan Kalimantan Tengah. Dengan kapasitas produksi listrik sebesar 30 MegaWatt dan rata-rata produksi listrik sebesar 136 GWh per tahun atau sekitar 10\% dari produksi total sistem kelistrikan di wilayah Kalimantan Selatan dan Kalimantan Tengah, PLTA ini mempunyai peran yang cukup penting dalam skema distribusi listrik pada jaringan interkoneksi listrik di wilayah Kalimantan Selatan dan Kalimantan Tengah. Waduk Ir. PM Noor yang dibangun dengan memanfaatkan aliran Sungai Riam Kanan, terletak di Desa Aranio, 25 $\mathrm{Km}$ di sebelah timur Kota Banjarbaru atau $60 \mathrm{~km}$ di sebelah timur Kota Banjarmasin. Waduk ini mempunyai kapasitas tampung sebesar 772 juta $\mathrm{m}^{3}$ dengan volume efektif sekitar 492 juta $\mathrm{m}^{3}$, luas permukaan efektif sekitar $68 \mathrm{~km}^{2}(6.800 \mathrm{Ha})$ dengan elevasi terendah untuk pola operasi waduk setinggi 53,00 mdpl, sementara elevasi tertinggi (pelimpas utama/service spillway) 59,86 mdpl dan elevasi banjir (pelimpas darurat/emergency spillway) 63,00 mdpl. Ratarata aliran masuk (inflow) selama setahun sekitar $39,77 \mathrm{~m} 3 /$ detik.

Hingga saat ini, PLTA Ir. PM Noor masih menjadi pembangkit dengan biaya operasi yang paling murah dalam sistem kelistrikan di wilayah Kalimantan Selatan dan Kalimantan Tengah. Tingkat keandalan PLTA ini sangat bergantung pada ketersediaan air yang tertampung di Waduk PLTA Ir. PM Noor. Sebagai pembangkit listrik yang juga ramah lingkungan, produksi listrik dari PLTA Ir. PM Noor diharapkan dapat berkontribusi secara optimal sepanjang tahun.

Secara umum tinggi muka air waduk Riam Kanan pada awal tahun hingga bulan Maret 2017 relatif masih dibawah rata-rata historisnya. Inflow sempat mengalami kenaikan di bulan Februari akan tetapi menurun kembali pada bulan Maret. 


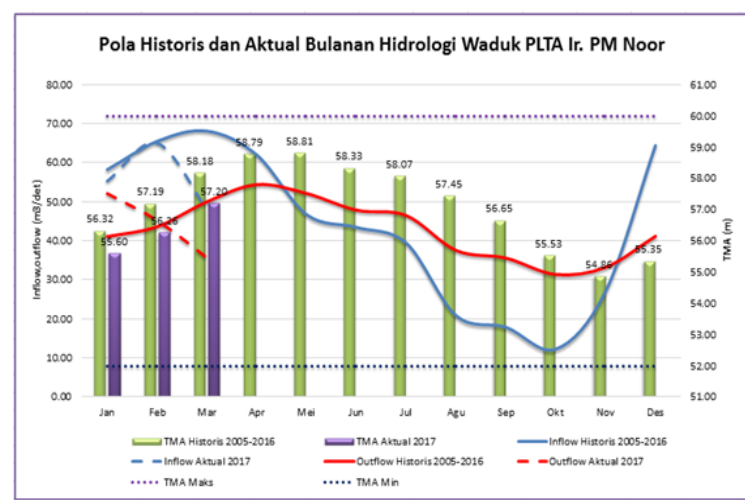

Gambar 1. Perbandingan kondisi aktual hidrologi Waduk PLTA Ir. PM Noor periode bulan Januari hingga Maret 2017 terhadap pola historisnya.

Kondisi hidrologi Waduk PLTA Ir. PM Noor sejak periode Januari hingga awal April 2017 seperti terlihat dalam Gambar 1.

Untuk mengatasi kondisi tersebut serta untuk menjaga ketersediaan air di PLTA Ir. PM Noor menghadapi musim kemarau tahun 2017 maka PT PLN (PERSERO) Wilayah Kalimantan Selatan dan Kalimantan Tengah bekerja sama dengan Balai Besar Teknologi Modifikasi Cuaca - Badan Pengkajian dan Penerapan Teknologi (BBTMC-BPPT) melaksanakan kegiatan penyemaian awan melalui Teknologi Modifikasi Cuaca (TMC) di Daerah Aliran Sungai (DAS) PLTA Ir. PM Noor.

Variasi iklim dan cuaca di wilayah Indonesia sangat dipengaruhi oleh sirkulasi Hadley dan Walker. Variasi curah hujan musiman di Indonesia terutama dipengaruhi oleh monsun (Moron et al., 2009) dan El Nino Southern Oscillation (Aldrian et al., 2007; Giannini et al., 2007; Hendon et al., 2007; Wolter \& Timlin, 2011). Faktor lain yang berpengaruh terhadap variasi hujan di Indonesia adalah Osilasi Madden Julian (Hermawan, 2010; Oh et al., 2012).

Dalam tulisan ini akan dibahas mengenai analisis cuaca pada saat pelaksanaan TMC di DAS PLTA Ir. PM Noor yang dilakukan pada tanggal 18 April hingga 17 Mei 2017 berdasarkan kondisi global, regional maupun lokal yang berpengaruh terhadap curah hujan di wilayah tersebut.

\section{METODE}

Data yang digunakan dalam tulisan ini adalah data regional serta data parameter cuaca permukaan hasil pengukuran di sekitar lokasi penyemaian awan. Data regional berupa tekanan udara, temperatur permukaan laut, penjalaran $\mathrm{MJO}$, angin gradient, citra satelit cuaca serta kelembapan udara. Sedangkan data lokal merupakan hasil pengukuran di lokasi penyemaian awan. Data yang diambil adalah data yang diperoleh selama periode pelaksanaan TMC yang berlangsung sejak tanggal 18 April s/d 17 Mei 2017.

\section{HASIL DAN PEMBAHASAN}

\subsection{Analisis Cuaca Global dan Regional \\ Kondisi cuaca di daerah target DAS PLTA} Ir. PM Noor yang berada di wilayah Provinsi Kalimantan Selatan selama pelaksanaan kegiatan TMC umumnya sangat dipengaruhi oleh beberapa fenomena global, regional, dan lokal. Fenomena global yang mempengaruhi kondisi cuaca di Indonesia antara lain El Niño, La Niña dan MJO (Madden Julian Osscillation). Fenomena regional yang mempengaruhi kondisi cuaca di Indonesia antara lain monsun, siklon tropis, pola tekanan pada level muka laut, suhu muka laut dan Eddy. Sementara kondisi lokal adalah topografi, radiasi matahari, kelembapan udara dan pola angin secara vertikal.

Sehubungan dengan hal tersebut di atas, analisis kondisi cuaca di Kalimantan Selatan umumnya dan khususnya di DAS PLTA Ir. PM Noor dilakukan dari unsur-unsur global, regional dan lokal. Ketiga unsur tersebut saling terkait dan mempengaruhi pertumbuhan awan di daerah target penyemaian awan, yang pada akhirnya berdampak pada jumlah curah hujan yang terjadi selama pelaksanaan kegiatan TMC.

\subsubsection{ENSO}

ENSO mempunyai pengaruh besar terhadap pembentukan awan hujan (cumulus) di sebagian besar wilayah Indonesia. ENSO terkait dengan perubahan nilai suhu muka laut di sepanjang ekuator Lautan Pasifik. Dalam kondisi normal suhu muka laut wilayah Lautan Pasifik Timur sepanjang ekuator lebih rendah dibandingkan dengan suhu muka laut wilayah Lautan Pasifik Barat sepanjang ekuator yang berujung di Benua Maritim (wilayah Indonesia). Kondisi ini sesuai dengan angin pasat di wilayah tropis yang bertiup dari Timur ke Barat. Arus laut akan sinking di wilayah Indonesia dan bergerak ke arah Timur dan muncul di Pasifik Timur (sebelah Barat pesisir Benua Amerika).

Apabila terjadi gangguan dengan munculnya gelombang Kelvin, yang bergerak dari Barat ke Timur, akan mempengaruhi sirkulasi arus laut. Sebagai akibatnya, suhu muka laut yang hangat akan bergeser ke arah Timur dan suhu muka laut di wilayah Lautan Pasifik Timur sepanjang ekuator akan relatif lebih hangat. Pasifik Timur akan menjadi daerah sinking arus laut dan bergerak ke arah Barat kemudian muncul (up welling) di wilayah Pasifik Barat (timur dari Benua Maritim). Keadaan ini akan mempengaruhi aktivitas konventif di Lautan Pasifik sepanjang ekuator. Kondisi ini dikenal dengan periode El Nino.

Dengan bergesernya aktivitas konveksi, aktivitas konveksi di wilayah Indonesia akan mengalami penurunan. Sebagai akibatnya jumlah hari hujan dan curah hujan akan turun di 
sebagian besar wilayah Indonesia dan mengakibatkan mayoritas wilayah Indonesia akan mengalami kekeringan.

Keadaan sebaliknya akan terjadi apabila suhu muka laut di wilayah Lautan Pasifik Barat lebih hangat dibandingkan normalnya. Aktivitas konveksi di wilayah Indonesia akan lebih tinggi yang menyebabkan curah hujan sangat tinggi di wilayah Benua Maritim. Keadaan seperti ini dikenal dengan periode La Niña.

Berdasarkan penelitian yang pernah dilakukan oleh Mulyana (2002) dan Sitompul \& Nurjani (2013), yang mengkaji tentang pengaruh ENSO terhadap curah hujan di Indonesia, bahwa El Nino sangat signifikan pengaruhnya terhadap hujan di Indonesia terutama pada bulan AgustusNovember.

Menurut El Nino/Southern Oscillation (ENSO) Diagnostic Discussion yang dikeluarkan Climate Prediction Center/NCEP/NWS April 2017, kondisi ENSO Netral dengan adanya kemungkinan menuju EL Nino lemah. Anomali SST pada bulan April 2017 dapat dilihat pada Gambar 2.
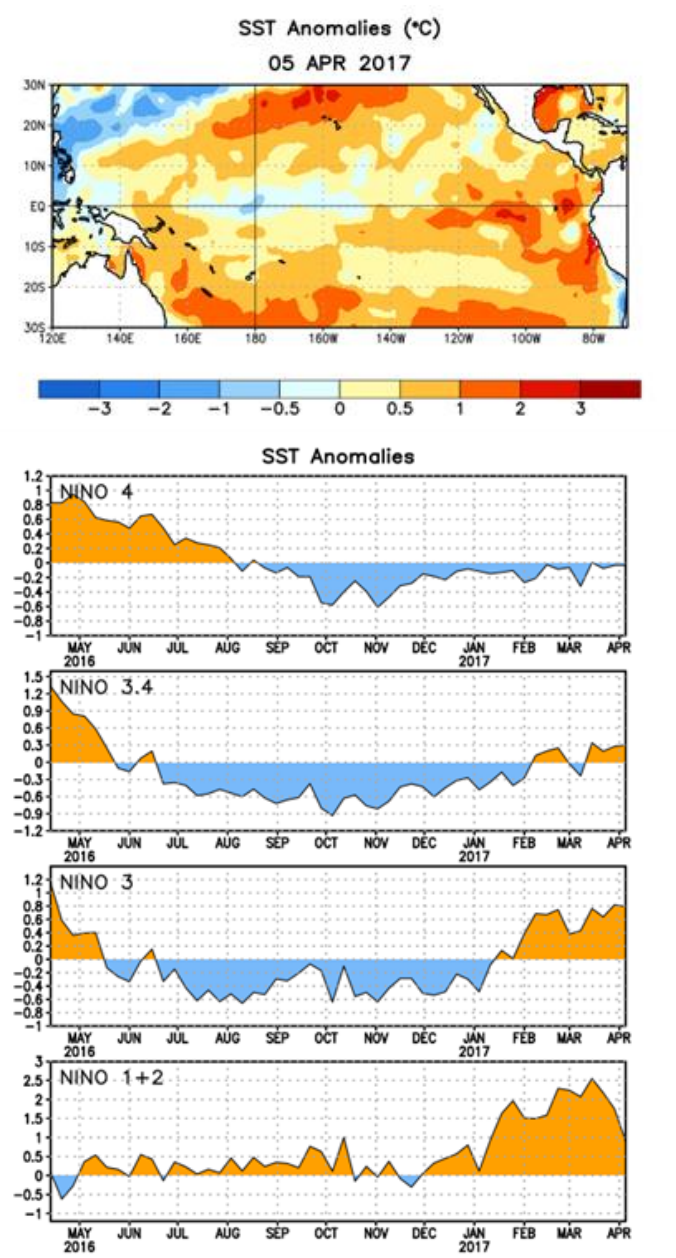

Gambar 2. Anomali SST (suhu muka laut) Lautan Pasifik Tengah dan Timur sekitar Ekuator bernilai $(-0.5)-(+1)^{\circ} \mathrm{C}$ sementara di perairan Indonesia nilai $(-1)-(+0.5)^{\circ} \mathrm{C}$ (atas), sementara Nino 3.4 bernilai $(+0.3)^{\circ} \mathrm{C}$ (bawah). (Diambil dari: ENSO Diagnostics Discussion - edisi April 2017).
Pada bulan Mei 2017, menurut El Niño/Southern Oscillation (ENSO) Diagnostic Discussion yang dikeluarkan Climate Prediction Center/NCEP/NWS kondisi masih ENSO Netral dengan adanya kemungkinan menuju EL Nino lemah. Anomali STT pada bulan Mei 2017 dapat dilihat pada Gambar 3.

\subsection{2. $M J O$}

MJO (Madden Julian Oscillation) merupakan fenomena gangguan yang bergerak dari Barat ke Timur di atas bagian yang hangat dari Lautan Hindia dan Pasifik (sekitar wilayah tropis). MJO merupakan variabilitas intra-musim di wilayah atmosfer sepanjang ekuator yang mempunyai periode bervariasi sekitar 40-50 hari. Fase dari gelombang ini disebut fase peningkatan aktivitas pertumbuhan awan dan fase penurunan pertumbuhan awan. MJO juga merupakan kombinasi antara sirkulasi atmosfer dan konvektif kuat di wilayah tropis. Pola sirkulasinya dapat diamati dengan mudah yang salah satu indikasinya adalah anomali pada jumlah curah hujan.
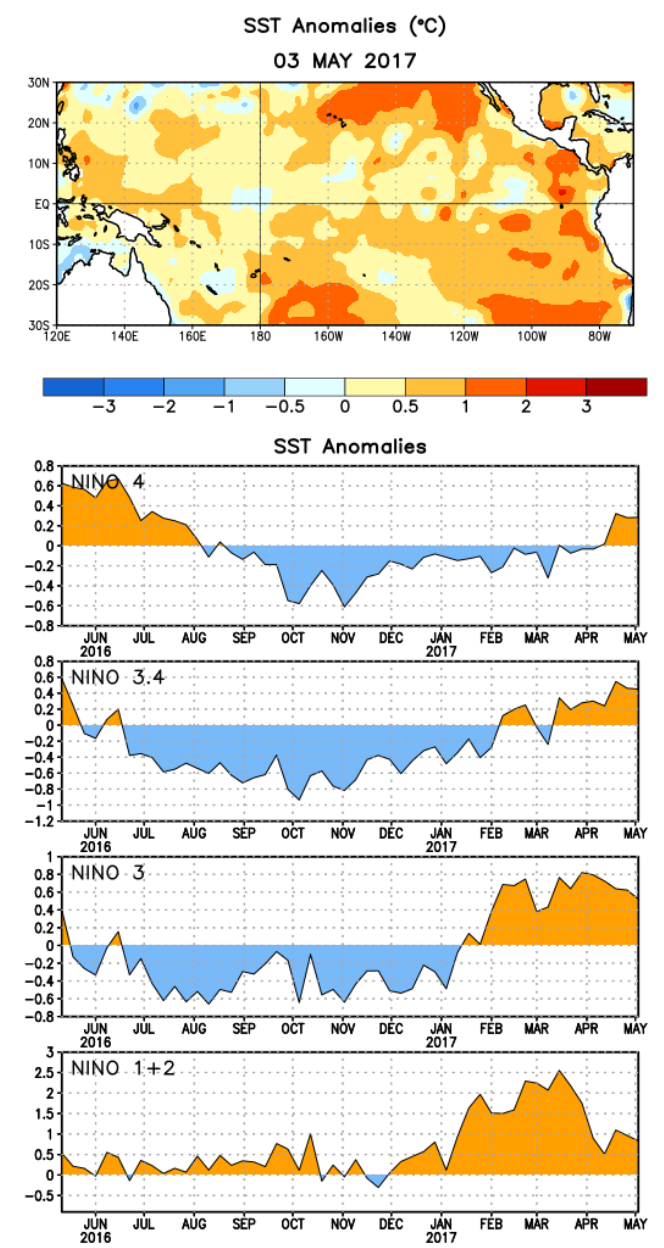

Gambar 3. Anomali SST (suhu muka laut)

Lautan Pasifik Tengah dan Timur sekitar Ekuator mencapai nilai $(+1)^{\circ} \mathrm{C}$ sementara di perairan

Indonesia bernilai $(+0.5)-(+1)^{\circ} \mathrm{C}$ (atas), sementara Nino 3.4 bernilai $(+0.4)^{\circ} \mathrm{C}$ (bawah). (Diambil dari: ENSO Diagnostics Discussion edisi Mei 2017). 


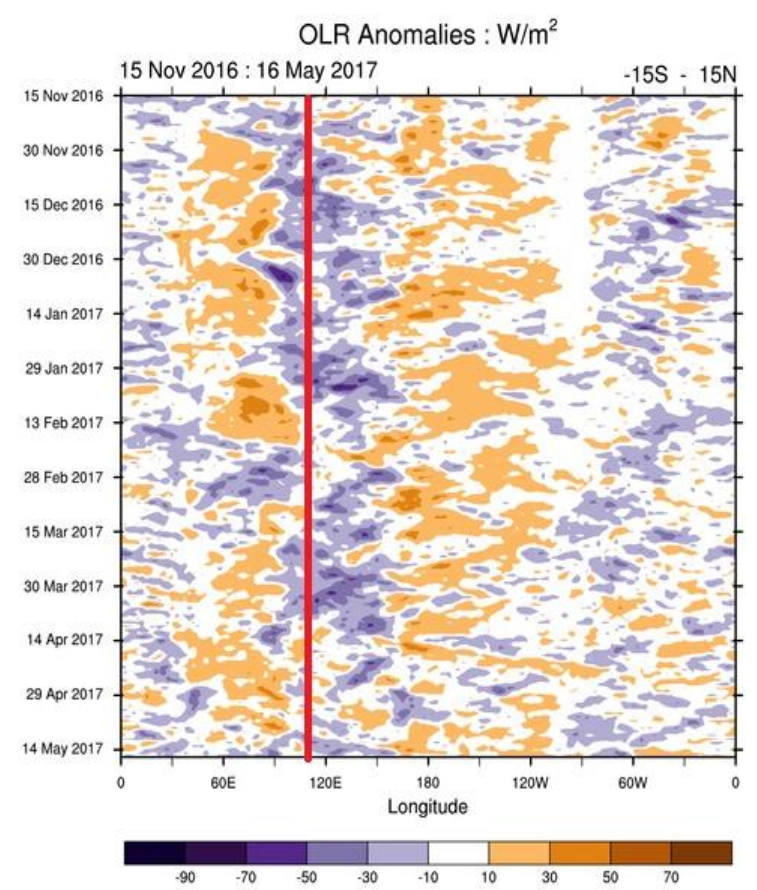

Gambar 4. Plot bujur-waktu OLR rata-rata $15^{\circ}$ LS - $15^{\circ}$ LU. Anomali positif (kuning/oranye) diasosiasikan dengan kurang menunjang presipitasi, sementara anomali negatif

(biru/magenta) diasosiasikan dengan kondisi mendukung pembentukan presipitasi, garis tegas pada sumbu $115^{\circ} \mathrm{BT}$ (garis merah) menunjukkan lokasi daerah target.

Dalam Gambar 4 diperlihatkan plot bujurwaktu rata-rata OLR antara $15^{\circ} \mathrm{LS}$ - $15^{\circ} \mathrm{LU}$. Anomali positif diasosiasikan dengan kurang menunjang presipitasi, sementara anomali negatif diasosiasikan dengan sangat mendukung pembentukan presipitasi. Dari Gambar 4 tampak bahwa wilayah Kalimantan Selatan (sekitar $115^{\circ}$ BT) pada pelaksanaan TMC tanggal 18 April - 17 Mei 2017 nilai anomali OLRnya lebih dominan negatif yang mengakibatkan banyaknya pertumbuhan awan.

\subsubsection{Angin Gradien}

Analisis angin gradien merupakan analisis pola angin dan aliran massa udara pada level 3000 feet, karena level tersebut sudah merupakan ketinggian free atmosfer maka arah angin digambarkan sejajar dengan garis isobar (garis yang memiliki tekanan udara yang sama). Kecepatan angin dapat diinterpretasikan dari kerapatan angin gradien. Dari analisis angin gradien dapat dianalisis kualitas massa udara yang masuk daerah target. Apakah massa udara cukup mengandung uap air atau tidak. Analisis angin gradien juga dapat menggambarkan adanya palung (daerah tekanan rendah) atau ridge (daerah tekanan tinggi) sehingga dapat diprakirakan kemungkinan kondisi pertumbuhan awan di daerah target. Contoh analisis angin gradien pada tanggal 11 Mei 2017 dapat dilihat pada Gambar 5.

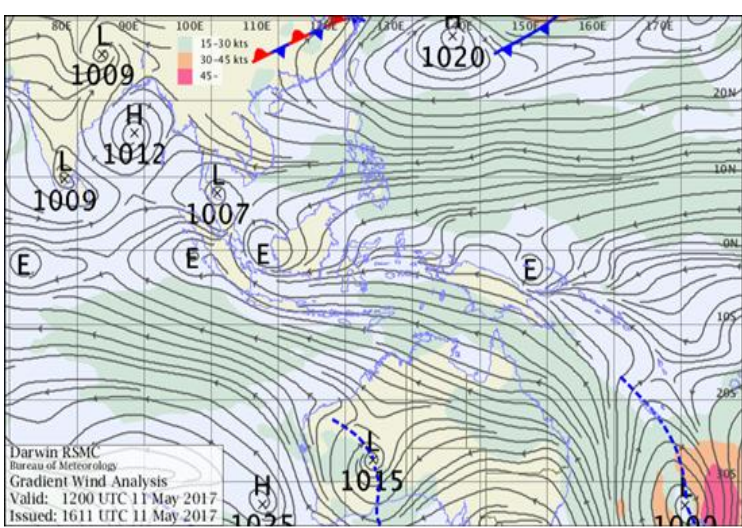

Gambar 5. Angin gradien tanggal 11 Mei 2017 jam 12.00 UTC. (Sumber: Bureau of Meteorology, Australia).

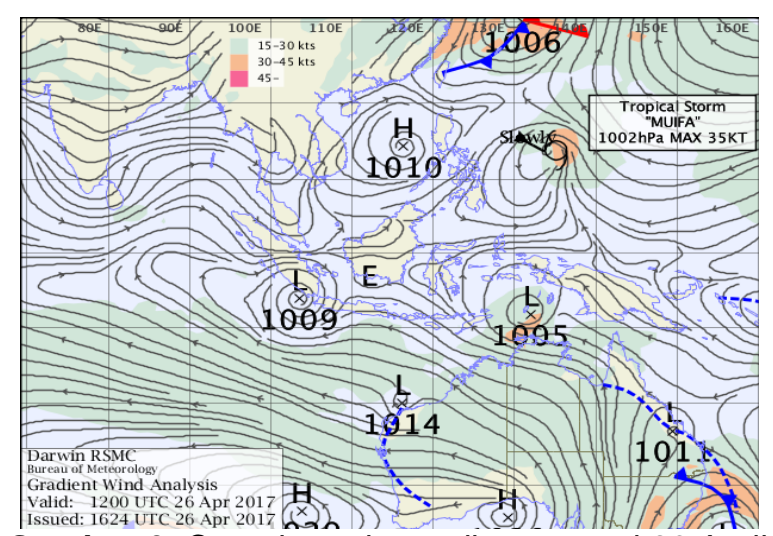

Gambar 6. Contoh angin gradien tanggal 26 April 2017 jam 12.00 UTC yang menunjukan adanya

TS Muifa di perairan sebelah timur Filipina.

(Sumber: Bureau of Meteorology, Australia).

Dari Gambar 5 tampak bahwa massa udara yang masuk daerah target didominasi massa udara yang berasal dari Lautan Pasifik Barat dan Laut Banda yang cukup mengandung uap air, karena SST di wilayah tersebut cukup hangat $\left(28.3^{\circ} \mathrm{C}-31^{\circ} \mathrm{C}\right)$, selain itu di daerah Kalimantan Selatan dan Sulawesi terdapat daerah konvergensi yang mendukung terjadinya pertumbuhan awan

Siklon tropis (tropical cyclone) adalah sistem tekanan rendah yang terbentuk di atas perairan hangat wilayah tropis. Semakin hangat semakin rendah tekanan udaranya dan akan membentuk garis isobar tertutup yang dapat menimbulkan kecepatan angin circular yang sangat tinggi. Bila kecepatan angin circular masih < 35 knots, gangguan tersebut disebut Depresi Tropis (Tropical Depression). Apabila tekanan udaranya turun terus dan kecepatan angin circularnya $\geq 35$ s.d. $<65$ knots gangguan tersebut menjadi Badai Tropis (Tropical Storm) dan akan diberi nama. Jika gangguan tersebut mencapai kecepatan $\geq 65$ knots akibat semakin rendahnya tekanan udara, gangguan tersebut akan disebut Siklon Tropis (Tropical Cyclone), yang kalau terjadi di wilayah Pasifik Barat disebut typhoon. 

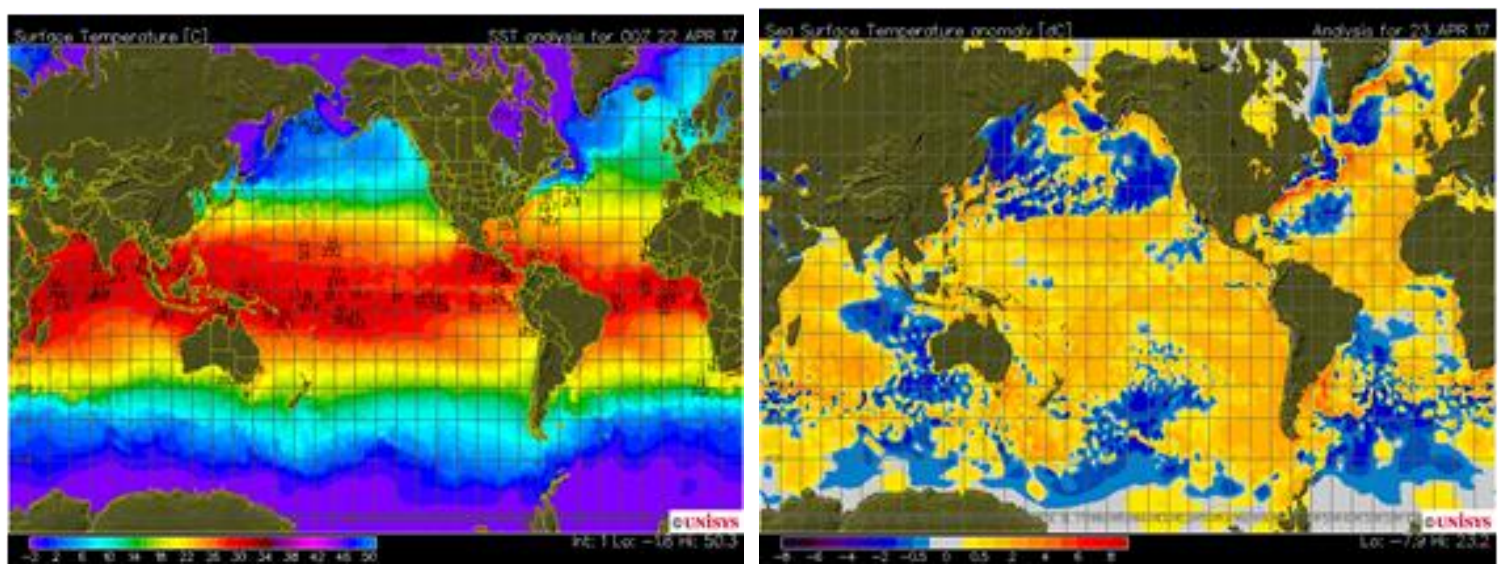

Gambar 7. Suhu Muka Laut/SST (atas) dan Anomali SST (bawah) yang terpantau pada tanggal 22 dan 23 April 2017 (sumber : Unisys). Selama kegiatan TMC berlangsung, SST di perairan sekitar Kalimantan umumnya berkisar $29-31^{\circ} \mathrm{C}$.

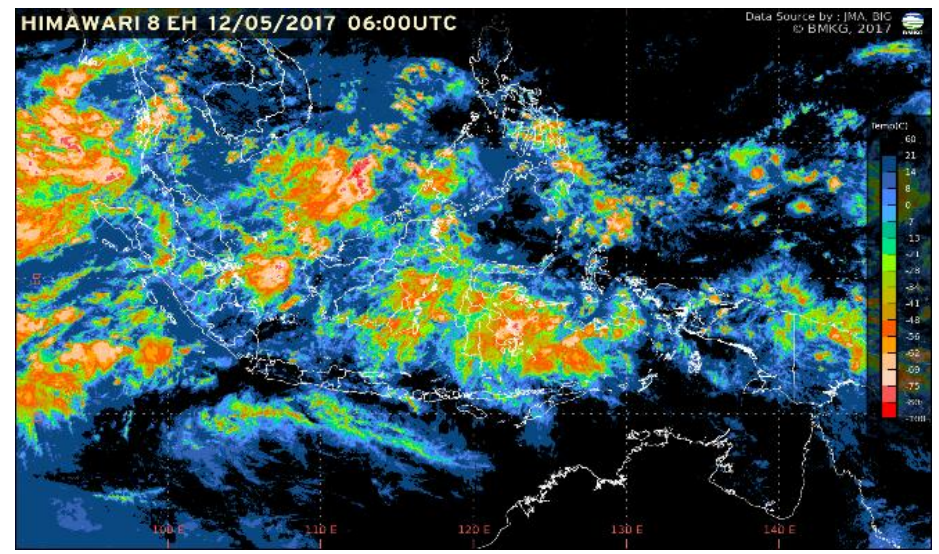

Gambar 8. Citra satelit kanal infra merah yang sudah diolah oleh BMKG tanggal 12 Mei 2017 pukul 06UTC/14:00 WITA. (sumber : BMKG). Tampak adanya awan Cu dengan puncak awan cukup tinggi, yang ditunjukan dengan warna jingga hingga putih, di sekitar daerah target.

Depresi Tropis, Badai Tropis dan Siklon Tropis dapat mempengaruhi pola analisis angin gradien yang berakibat akan mempengaruhi kemungkinan pertumbuhan awan di suatu daerah. Selama kegiatan TMC, gangguan tropis yang terjadi yaitu Tropical Storm (TS) Muifa (Gambar 6), tetapi karena lemah dan durasi masa hidupnya hanya satu hari sehingga tidak terlalu berpengaruh terhadap kondisi cuaca di daerah target.

\subsubsection{Suhu Muka Laut}

Suhu permukaan laut sangat mempengaruhi suplai uap air dari laut ke daerah target seiring pola angin pada saat itu. Suhu permukaan laut selama periode pelaksanaan TMC, di perairan Timur dan Selatan Kalimantan Selatan berkisar antara $29-31^{\circ} \mathrm{C}$. Hal ini menunjukkan bahwa wilayah perairan di sekitar Kalimantan Selatan cukup hangat sehingga suplai massa udara basah yang banyak mengandung uap air cukup besar.

\subsubsection{Citra Satelit}

Citra satelit digunakan untuk melihat tutupan dan jenis awan di sekitar daerah target. Citra satelit kanal infra merah yang sudah diolah oleh BMKG digunakan dalam analisis ini. Kelemahan dari citra satelit adalah grid pointnya yang besar sehingga tidak bisa melihat citra awan secara detil. Kanal infra merah pengukurannya berdasarkan suhu. Semakin dingin suhunya, warna objek semakin putih. Sebaliknya semakin panas suhunya, warna objek semakin hitam. Contoh citra satelit yang sudah diolah oleh BMKG seperti yang terlihat pada Gambar 8.

\subsubsection{Kelembapan Udara}

Kelembapan udara relatif (Relative Humidity) merupakan ukuran dari nilai relatif kandungan uap air di udara, dimana semakin tinggi nilai kelembapan udara maka massa udara akan semakin jenuh, massa udara yang jenuh dengan uap air merupakan indikasi baik untuk pertumbuhan awan. Gambar 9 adalah contoh nilai kelembapan udara untuk tiga lapisan, di $850 \mathrm{mb}$ (5000 feet), $700 \mathrm{mb}$ ( 10.000 feet), dan 500 $\mathrm{mb}$ (18.000 feet) pada saat pelaksanaan TMC.

Selama periode pelaksanaan TMC, nilai kelembapan udara di wilayah Kalimantan Selatan pada lapisan $850 \mathrm{mb}$ umumnya cukup basah (65$90 \%$ ), pada lapisan $700 \mathrm{mb}$ juga relatif masih basah $(60-95 \%)$ dan pada lapisan $500 \mathrm{mb}$ juga 


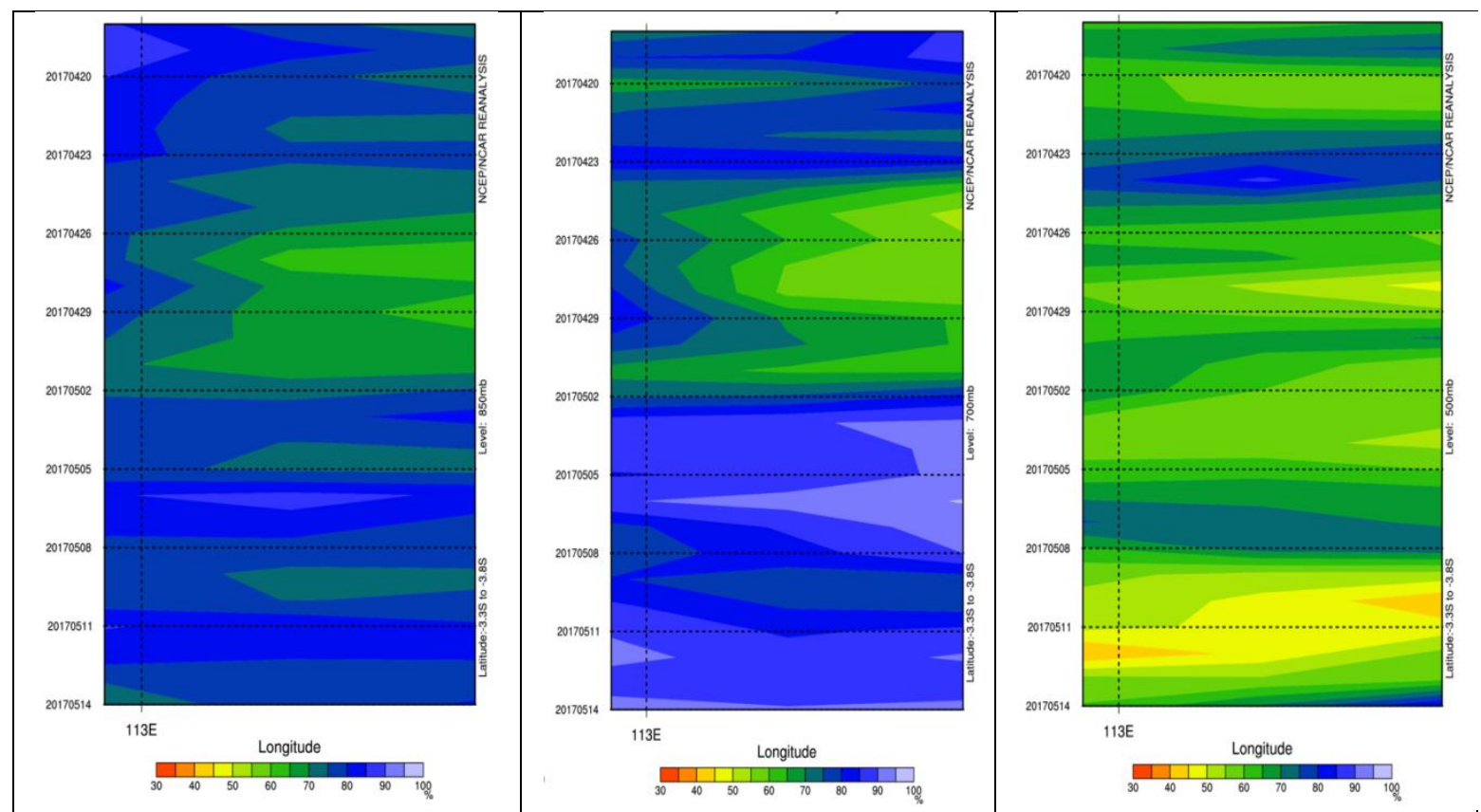

Gambar 9. Contoh nilai kelembapan udara di wilayah DAS PLTA Ir. PM Noor (longitude : 112 s/d 118 BT dan latitude : $3.8 \mathrm{~s} / \mathrm{d} 3.3 \mathrm{LS}$ ) dari tanggal 18 April - 17 Mei 2017 untuk lapisan 850mb (kiri), 700mb (tengah) dan $500 \mathrm{mb}$ (kanan). (Sumber : NOAA/ESRL/PSD).

masih relatif basah $(60-80 \%)$, kecuali pada tanggal 10-12 Mei 2017 kelembapan udara berkisar $40-50 \%$. Secara keseluruhan kondisi kelembapan udara di wilayah Kalimantan Selatan cukup basah sehingga uap air yang tersedia di wilayah target cukup mendukung untuk proses pembentukan awan potensial.

\subsection{Analisis Cuaca Lokal}

Untuk mengetahui cuaca lokal di DAS PLTA Ir. PM Noor, ditempatkan Pos Pengamatan Meteorologi (Posmet) di dua lokasi, yaitu Posmet Rantau Bujur yang terletak di dalam DAS PLTA Ir. PM Noor dan Posmet Bajuin (Pelaihari) yang terletak di barat daya DAS PLTA Ir. PM Noor. Fungsi utama kedua posmet tersebut adalah untuk melihat pergerakan dan pertumbuhan awan serta mengukur parameter cuaca permukaan.

Radar milik BMKG Wilayah Kalimantan Selatan tipe C-band juga dimanfaatkan untuk melihat perkembangan awan di daerah target secara real time. Posisi radar berada di Stasiun Klimatologi Banjarbaru. Pengamatan dilakukan secara real time dan informasi radar dalam bentuk citra dianalisis perkembangan awan dan pergerakannya. Dengan adanya informasi citra radar secara real time maka pemantauan pertumbuhan awan di daerah target menjadi lebih optimal.

\subsubsection{Analisis Angin Lapisan Atas}

Analisis angin lapisan atas dilakukan untuk mengetahui arah dan kecepatan angin secara vertikal di lokasi kegiatan. Meskipun analisis angin gradien menggambarkan kondisi angin secara regional, masih perlu analisis data in situ

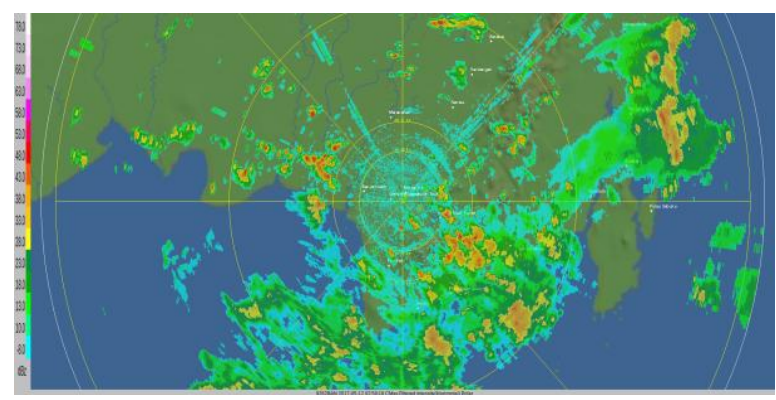

Gambar 10. Citra radar C-band yang berada di Banjar Baru, tanggal 12 Mei 2017 jam 03.00UTC. Nampak populasi awan berada di sebelah timur laut hingga tenggara DAS PLTA Ir. PM Noor.

dan real time yaitu pengamatan angin atas di Posmet. Selama kegiatan TMC, angin atas dominan dari Timur Laut - Tenggara. dengan kecepatan yang bervariasi antara 1-15 knot.

\subsubsection{Analisi Data C-Band Radar}

Citra C-band radar dapat menginformasikan jenis awan dan kualitas awan yang ada. Dengan data radar cuaca maka dapat diketahui penampang awan sehingga dapat diketahui volume awan tersebut, disamping itu juga kandungan presipitasi juga dapat diprakirakan dari nilai echo (dalam dBz), semakin besar nilai echo (dBz) semakin banyak kandungan air di dalam awan tersebut. Sebagai contoh citra C-band radar Banjarbaru dapat dilihat pada Gambar 10.

\subsection{Curah Hujan}

Informasi curah hujan di DAS PLTA Ir. PM Noor selama periode kegiatan TMC disajikan dalam bentuk spasial maupun temporal. 


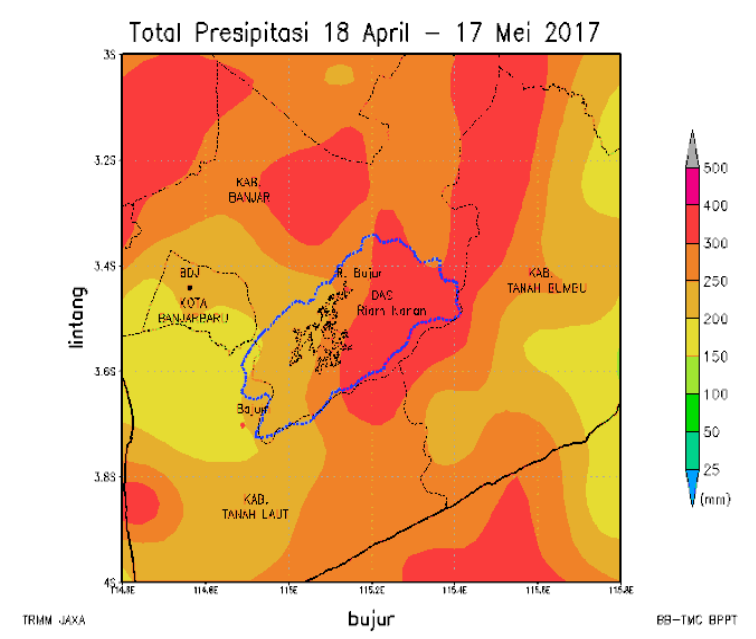

Gambar 11. Curah hujan spasial wilayah di DAS

PLTA Ir. PM Noor selama periode kegiatan TMC tanggal 18 April - 17 Mei 2017.

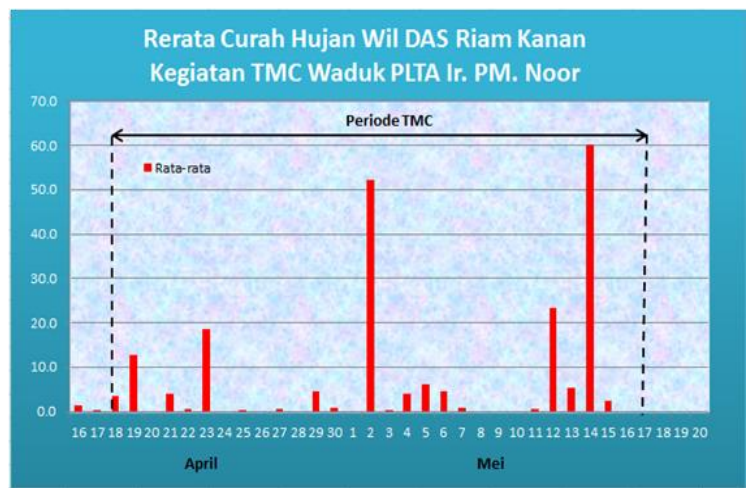

Gambar 12. Grafik rerata curah hujan wilayah di DAS PLTA Ir. PM Noor selama periode kegiatan TMC.

Informasi spasial curah hujan selama kegiatan ditampilkan dalam Gambar 11, sementara informasi curah hujan secara temporal disajikan dalam Gambar 12. dan Tabel 1.

Gambar 11 adalah peta curah hujan spasial selama kegiatan TMC yang diambil dari data TRMM Jaxa.

Dari Gambar 11 tersebut di atas terlihat bahwa curah hujan di wilayah DAS PLTA Ir. PM Noor selama periode kegiatan TMC berkisar antara 150-400 mm. Curah hujan tertinggi terjadi di bagian Timur dan Timur Laut DAS PLTA Ir. PM Noor dengan intensitas berkisar 300-400 mm sedangkan curah hujan terendah terjadi di bagian Barat Daya DAS PLTA Ir. PM Noor dengan intensitas berkisar 150-200 mm.

Berbeda dengan penyajian informasi curah hujan secara spasial yang menggunakan data TRMM, dalam Gambar 12 dan Tabel 1 berikut menyajikan informasi curah hujan secara temporal dengan menggunakan data curah hujan dari 8 (delapan) penakar curah hujan yang terpasang di sekitar DAS Ir. PM Noor, yaitu di Damsite, Kalaan, Sungai Luar, Tiwingan Lama, Paau, Bukit Batas, Posmet Rantau Bujur dan Posmet Bajuin.
Tabel 1. Curah hujan di beberapa lokasi penakar di sekitar DAS PLTA Ir. PM Noor selama periode kegiatan TMC.

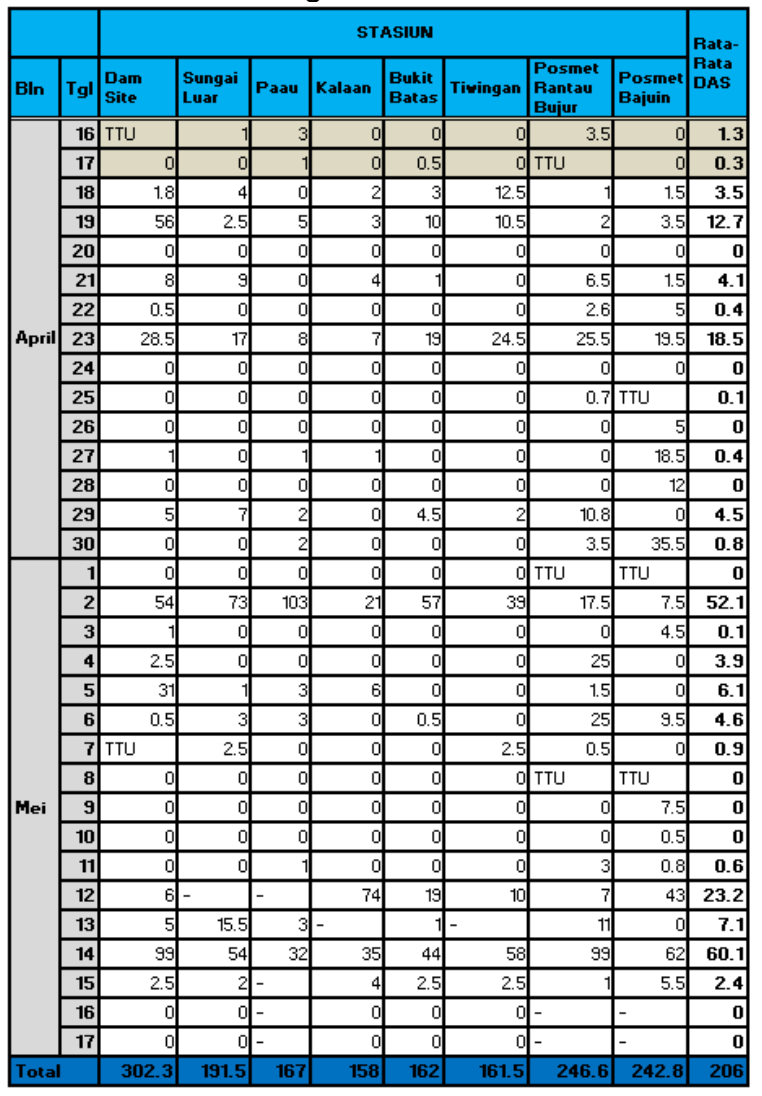

Dari Gambar 12 dan Tabel 1 dapat diketahui bahwa selama periode pelaksanaan TMC yang berlangsung sejak tanggal 18 April - 17 Mei 2017, hampir setiap harinya selalu terjadi hujan di wilayah DAS PLTA Ir. PM Noor. Total rata-rata curah hujan wilayah di DAS PLTA Ir. PM Noor selama periode pelaksanaan TMC adalah sebesar 205,7 mm. Stasiun Damsite dengan total curah hujan sebesar 302,3 mm merupakan lokasi yang paling tinggi intensitas curah hujannya, sementara yang terendah adalah di Stasiun Kalaan dengan total curah hujan sebesar 158,0 $\mathrm{mm}$.

Selama periode pelaksanaan kegiatan TMC, intensitas curah hujan tertinggi terjadi pada tanggal 14 Mei 2017, dengan rerata curah hujan wilayah mencapai sebesar $60,1 \mathrm{~mm}$. Pada tanggal tersebut, sebagian besar lokasi penakar curah hujan mempunyai intensitas curah hujan $>$ $30 \mathrm{~mm} /$ hari, yaitu di Damsite $(99,0 \mathrm{~mm})$, Sungai Luar (54,0 mm), Paau (32,0 mm), Kalaan (35,0 $\mathrm{mm})$, Bukit Batas $(44,0 \mathrm{~mm})$, Tiwingan $(58,0$ $\mathrm{mm})$, Posmet Rantau Bujur $(99,0)$, Posmet Bajuin $(62,0 \mathrm{~mm})$.

\section{KESIMPULAN}

Selama pelaksanaan TMC di DAS PLTA Ir PM Noor pada tanggal 18 April - 17 Mei 2017 menunjukkan kondisi ENSO netral menuju lemah, sedangkan nilai anomali OLRnya lebih 
dominan negatif yang menunjukkan banyaknya pembentukan dan pertumbuhan awan-awan hujan yang potensial. Dengan demikian fenomena ENSO dan MJO mempengaruhi kondisi cuaca di daerah target. Selama kegiatan TMC. Dari kondisi cuaca yang ada dapat disimpulkan:

1. Kondisi cuaca di DAS PLTA Ir PM Noor dipengaruhi oleh gabungan dari berbagai faktor meteorologi seperti fenomena ENSO dan MJO.

2. Gradien angin menunjukkan massa udara yang masuk daerah target didominasi massa udara yang berasal dari Lautan Pasifik Barat dan Laut Banda yang cukup mengandung uap air, selain itu di daerah Kalimantan Selatan dan Sulawesi terdapat daerah konvergensi yang mendukung terjadinya pertumbuhan awan.

3. Secara keseluruhan kondisi kelembapan udara di wilayah Kalimantan Selatan cukup basah sehingga uap air yang tersedia di wilayah target cukup mendukung untuk proses pembentukan awan potensial.

4. Pada dasarian 3 bulan April 2017 adanya TS Muifa tidak terlalu berpengaruh terhadap cuaca di DAS PLTA Ir PM Noor karena lemah dan durasi masa hidupnya hanya satu hari

5. Total curah hujan wilayah di DAS PLTA Ir. PM Noor selama periode pelaksanaan TMC adalah sebesar 205,7 mm. Curah hujan tertinggi terjadi pada periode akhir pelaksanaan TMC yaitu pada tanggal 14 Mei 2017, dengan curah hujan wilayah sebesar $60,1 \mathrm{~mm}$.

\section{DAFTAR PUSTAKA}

Aldrian, E., Gates, L.D., Widodo, F.H. (2007). Seasonal Variability of Indonesian Rainfall in $\mathrm{ECHAM}_{4}$ Simulations and in the Reanalyses: The Role of ENSO. Theoretical and Applied Climatology, 87, 41-59. doi: 10.1007/s00704-006-0218-8

Chen, D., Cane, M.A. (2008). El Nino Prediction and Predictability. Journal of Computational Physics, 227(7), 36253640. doi: 10.1016/j.jcp.2007.05.014

Djuric, D. (1994) Weather Analysis. Prentice-Hall, New Jersey. 304 pp.
Giannini, A., Robertson, A.W., Qian, J.-H. (2007). A Role for Tropical Tropospheric Temperature Adjusment to El NinoSouthern Oscillation in the Seasonality of Monsoonal Indonesia Precipitation Predictability. Journal of Geophysical Research, 112(D16110), . doi: 10.1029/2007JD008519

Hendon, H.H., Thompson, D.W.J., Wheeler, M.C. (2007). Australian Rainfall and Surface Temperature Variations Associated with the Southern Hemisphere Annular Mode. Journal of Climate, 20(11), 2452-2467. doi: 10.1175/JCLI4134.1

Hermawan, E. (2010). Analisis Struktur Vertikal MJO Terkait dengan Aktivitas Super Cloud Clusters (SCCs) di Kawasan Barat Indonesia. Jurnal Sains Dirgantara, 8(1), 25-42.

Moron, V., Robertson, A.W., Boer, R. (2009). Spatial Coherence and Seasonal Predictability of Monsoon Onset over Indonesia. Journal of Climate, 22(3), 840850. doi: 10.1175/2008JCLI2435.1

Mulyana, E. (2002). Hubungan antara ENSO dengan Variasi Curah Hujan Indonesia. Jurnal Sains \& Teknologi Modifikasi Cuaca, 3(1), 1-4.

Oh, J.-H., Kim, K.-Y., Lim, G.-H. (2012). Impact of MJO on the Diurnal Cycle of Rainfall over the Western Maritime Continent in the Austral Summer. Climate Dynamics, 38, 1167-1180. doi: 10.1007/s00382-0111237-4

Sitompul, Z., Nurjani, E. (2013). Pengaruh El Nino Southern Oscillation (ENSO) terhadap Curah Hujan Musiman dan Tahunan di Indonesia. Jurnal Bumi Indonesia, 2(1), 11-18.

Wheeler, M.C., Hendon, H.H. (2004). An AllSeason Real-Time Multivariate MJO Index: Development of an Index for Monitoring and Prediction. Monthly Weather Review, 132(8), 1917-1932. doi: 10.1175/15200493(2004)132<1917:AARMMI>2.0.CO;2

Wolter, K., Timlin, M.S. (2011). El Nino/Southern Oscillation Behaviour since 1871 as Diagnosed in an Extended Multivariate ENSO Index (MEl.ext). International Journal of Climatology, 31(7), 1074-1087. doi: $10.1002 /$ joc. 2336 